\title{
DNA Repair Protein Complementing XP-G Cells
}

National Cancer Institute

\section{Source}

National Cancer Institute. DNA Repair Protein Complementing XP-G Cells. NCI

Thesaurus. Code C21460.

DNA repair protein complementing XP-G cells (1186 aa, $133 \mathrm{kDa}$ ) is encoded by the human ERCC5 gene. This protein plays a role in the repair of UV-induced DNA damage. 